\title{
MIMICKERS OF LUNG CANCER: WHEN NOT TO PERFORM A PULMONARY BIOPSY - CASE REPORTS
}

\author{
Bețianu Cezar-Iulian, Ion Giorgiana, Goicea Mihaela \\ 'Carol Davila' Central Military Emergency University Hospital, Bucharest, Romania \\ Corresponding author: \\ Ion Giorgiana, MD, Department of Radiology and Medical Imaging, 'Carol Davila' Central \\ Military Emergency University Hospital, Bucharest, Romania \\ Corresponding email: pavaloiu.giorgiana@gmail.com
}

\begin{abstract}
Background. Percutaneous lung biopsy is an essential step in the management of equivocal lung lesions. Percutaneous lung biopsy is a minimally-invasive procedure with a diagnostic accuracy of more than $90 \%$ and a major complication rate of less than $6 \%{ }^{(1)}$. Because it is an easy, rapid and safe procedure, percutaneous lung biopsy has become an attractive diagnostic tool for both radiologists and clinicians. However, before planning a percutaneous lung biopsy, the radiologist must carefully evaluate the lung lesion in order to avoid unnecessary lung biopsies.
\end{abstract}

Aim. The aim of this paper is to evaluate pulmonary pseudolesions that do not require biopsy and to point out key imaging features that help differentiate these lesions from lung cancer.

Case presentations. The authors are analyzing six cases of pulmonary pseudolesions (round pneumonia, pulmonary infarction, round atelectasis, pulmonary artery pseudoaneurysm, pulmonary sequestration and inflammatory pseudotumour) encountered in our hospital that were referred to biopsy as suspicious for malignancy.

Conclusions. There is a wide range of conditions that produce imaging features that mimic lung cancer. However, a careful evaluation of the lesion along with relevant clinical and laboratory findings help make an accurate diagnosis.

Keywords: pulmonary cancer, pulmonary pseudolesions, lung biopsy.

\section{Rezumat}

Introducere. Biopsia pulmonară percutanată reprezintă o etapă esențială în managementul leziunilor pulmonare echivoce. Biopsia pulmonară percutanată este o procedură miniminvazivă având o acuratețe de diagnostic de peste $90 \%$ și o rată de complicații majore de sub $6 \%{ }^{(1)}$. Fiind o procedură facilă, rapidă și sigură, biopsia pulmonară percutanată a devenit o unealtă de diagnostic atractivă atât pentru clinicieni, cât și pentru radiologi. Cu toate acestea, înainte de a planifica o biopsie percutanată, radiologul trebuie să evalueze atent leziunea pulmonară pentru a evita biopsiile ce nu sunt necesare. 


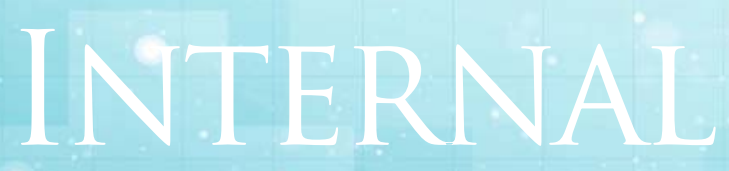

Clinical cases

Scop. Scopul acestei lucrari este de a analiza pseudoleziunile pulmonare care nu necesită biopsie și de a evidenția caracteristicile imagistice care ajută la diferențierea acestora de leziunile maligne.

Prezentări de cazuri. Sunt analizate 6 cazuri clinice de pseudoleziuni pulmonare (pneumonie rotundă, pseudoanevrism de arteră pulmonară, sechestru pulmonar, pseudotumoră inflamatorie) internate în Spitalul Universitar de Urgență Militar Central 'Carol Davila', cu indicația de biopsie pulmonară percutanată.

Concluzii. Există o gamă largă de entități pulmonare ce pot imita leziunile maligne. Totuși, o evaluare atentă a leziunii, precum și integrarea în contextul clinic-biologic al pacientului ajută la stabilirea unui diagnostic corect.

Cuvinte cheie: cancer pulmonar, pseudoleziuni pulmonare, biopsie pulmonară

\section{Introduction}

Transthoracic lung biopsy is the keystone for equivocal pulmonary lesions. Percutaneous lung biopsy is a minimally-invasive procedure with a diagnostic accuracy of more than $90 \%$ and a major complication rate of less than $6 \%{ }^{(1)}$. According to British Thoracic Society for guided lung biopsy, indications for pulmonary biopsies, are: lung lesions recently discovered or lesions that cannot be evaluated by bronchoscopy, multiple pulmonary lesions in a healthy patient, and persistent focal pulmonary lesions $^{(2)}$. Biopsy is required not only to confirm the nature of the lesion but also to plan the treatment of lung cancer depending on the immunohistochemistry. Although percutaneous lung biopsy has a low rate of complications, some of them may lead to death, such as hemothorax or air embolism. Consequently, the indications for percutaneous lung biopsy must be cautiously revised and every case should be carefully evaluated.

There is a wide range of pulmonary pseudolesions that may mimic lung cancer both clinically and radiologically. Pulmonary pseudolesions described in the literature are round atelectasis, round pneumonia, hamartoma, sclerosing hemangioma, tuberculoma, inflammatory pseudotumor, etc. In this paper, we describe the most common pulmonary pseudolesions encountered in our clinical practice, such as round pneumonia, round atelectasis, 
pulmonary infarcts, pulmonary sequestration, pseudoaneurysm and inflammatory pseudotumour. The purpose of the paper is to point out the key imaging features of these pulmonary pseudolesions that can lead to an accurate diagnosis. The radiologist must be familiar with these diseases in order to avoid unnecessary pulmonary biopsies.

\section{Case presentations}

A series of patients with pulmonary focal lesions admitted between 2016 and 2018 in the 'Carol Davila' Central Military Emergency University Hospital, Bucharest, Romania, is presented. The six cases presented were referred to the Department of Radiology for percutaneous image-guided lung biopsy as suspicious for malignant lesions. Each case was carefully analyzed by re-evaluation of the thoracic CT scan along with clinical and paraclinical information from the patient chart.

\section{Case no. 1- round pneumonia (figure 1)}

A 55-year old male patient is referred to thoracic CT scan and biopsy after an accidental discovery of a focal right lung lesion seen at the thoracic spine MRI. The patient complaints were non-specific: back pain, weakness, fatigue, mild cough. Laboratory findings were within normal limits. The follow-up at 4 and 6 months clearly demonstrate the regression of the lung lesion.

\section{Case no. 2 - pulmonary infarction (figure} 2)

A 62-year old male patient is admitted to the hospital for shortness of breath, dry cough and thoracic pain, symptoms that started suddenly several days before. The discussion with the patient points out relevant information for the diagnosis: he travelled 8 hours by train a week before.

Case no. 3 - round atelectasis (figure 3 )

A pulmonary mass is discovered in a 68-year old patient with a history of pneumonia and left pleural fluid. Because the patient was a heavy smoker, a lung cancer was suspected. However, a careful evaluation of the lung lesion and the association with the pleural fluid, help established the diagnosis.

\section{Case no. 4 - pulmonary pseudoaneurysm} (figure 4)

A focal pulmonary lesion is discovered in a 36-year old patient after a routine chest radiography. The patient was asymptomatic at that moment and the laboratory findings were normal.

\section{Case no.5 - pulmonary sequestration} (figure 5)

A left lung mass is described in young patient with recurrent left pneumonia. Due to the recurrence of the pulmonary infection, a thoracic CT was performed.

\section{Case no.6 - inflammatory pseudotumor} (figure 6)

A 38-year old male patient is referred to thoracic CT scan after the discovery of a right pulmonary mass seen on the chest radiography. The patient described flu-like symptoms. Laboratory findings revealed inflammatory syndrome and leukocytosis. One important mention is that the patient is a veterinary doctor.

\section{Discussions}

Many lesions involving the lung, the pleura or the vascular structures have the propensity to mimic lung cancer. In this paper, we 


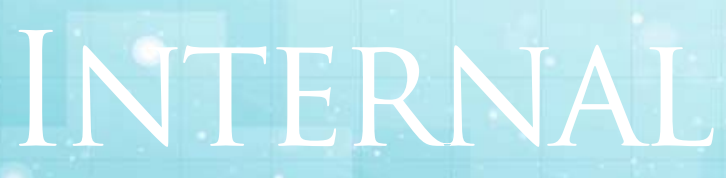

Clinical cases

evaluate six pulmonary pseudolesions encountered in our hospital that were mistaken for lung cancer.

\section{Round pneumonia}

Round pneumonia refers to any pneumonia that presents as a nodule or 'coin lesion' of the lung. Round pneumonia is considered a pediatric disease; in adults, it is a rare disease, accounting for less than $1 \%$ of 'coin lesions' of the lung. Regarding the physiopathology of round pneumonia, there have been described two theories. One of them postulates that the trigger of the disease is an infectious focus that expands centrifugally through the canals of Lambert or pores of Kohn. The other theory holds that round pneumonia develops mainly in pediatric patients because children have undeveloped pathways of collateral ventilation (pores of Kohn and canals of Lambert) ${ }^{(3)}$. This explains why round pneumonia appears as a compact area of consolidation without softer margins in children.

Clinically, patients may be asymptomatic or they may present with symptoms with acute or subacute pneumonia. Sometimes, the symptoms may be mild, mimicking a viral respiratory disease or a bronchitis.

Imaging findings show a round pulmonary lesion, with slightly ill-defined margins, most often located in the posterior segments or lower lobes. On CT scan, round pneumonia appears as a heterogeneous mass of softtissue attenuation, with satellite lesions and pleural thickening. Air bronchogram may be present but this sign is not helpful because it may also appear in bronchioalveolar carcinoma or adenocarcinoma. Pleural thickening is found in peripheral lesions because of associated inflammatory reaction. In children, round pneumonia most often presents with sharp margins because of undeveloped pathways of collateral ventilation.

\section{Pulmonary infarction}

Pulmonary infarction is a common complication of pulmonary embolism, occurring in about $15 \%$ of patients with PE. In pulmonary infarction, consolidation is due to alveolar filling with blood, with inflammatory reaction around central necrosis. Pulmonary embolism leads to a higher pressure in bronchial arteries. Alveolar hemorrhage is the result of increased vascular permeability and capillary endothelial injury triggered by pulmonary hypertension.

On CT scan, pulmonary infarction appears as a wedge-shaped juxtapleural consolidation (Hampton hump), with central areas of lowattenuation, with no enhancement and no air bronchogram. The presence of internal lucencies in the center of a peripheral consolidation has a $98 \%$ specificity and $46 \%$ 


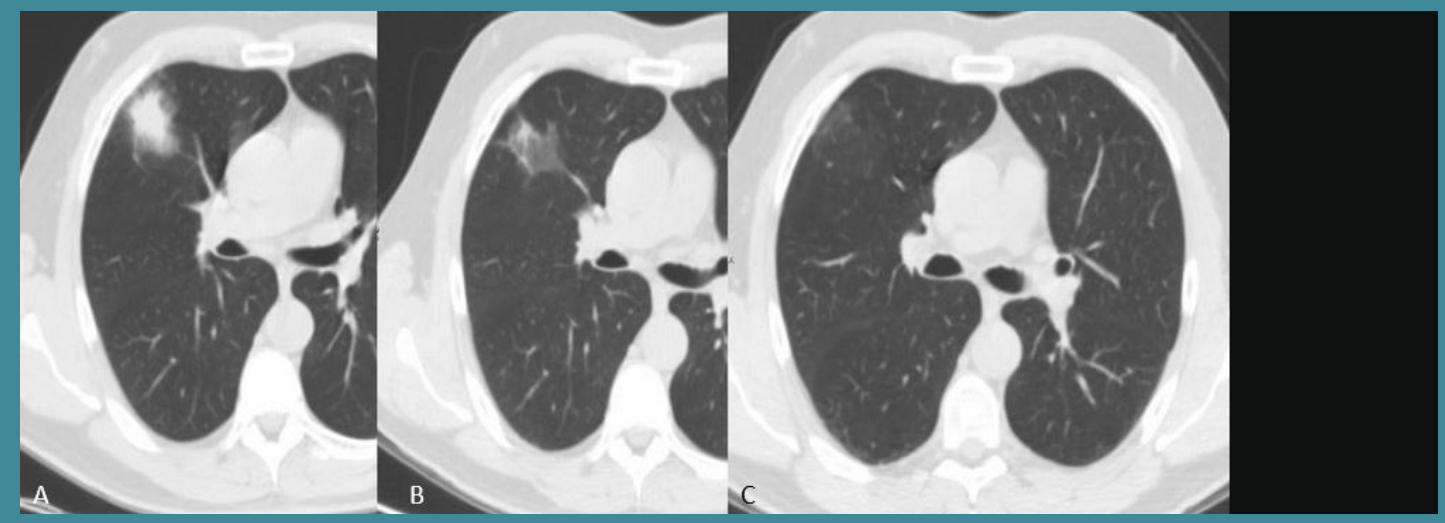

Figure 1. A. Round pneumonia. Axial CT scan shows a pulmonary lesion in the anterior segment of the right upper lobe, with ill-defined margins, surrounded by ground-glass opacity. The lesion was discovered incidentally while performing a thoracic spine MRI in a 55-year old patient complaining of back pain. B,C. Follow up CT scans at 1 and 3 months later show resolution of the pulmonary lesion.

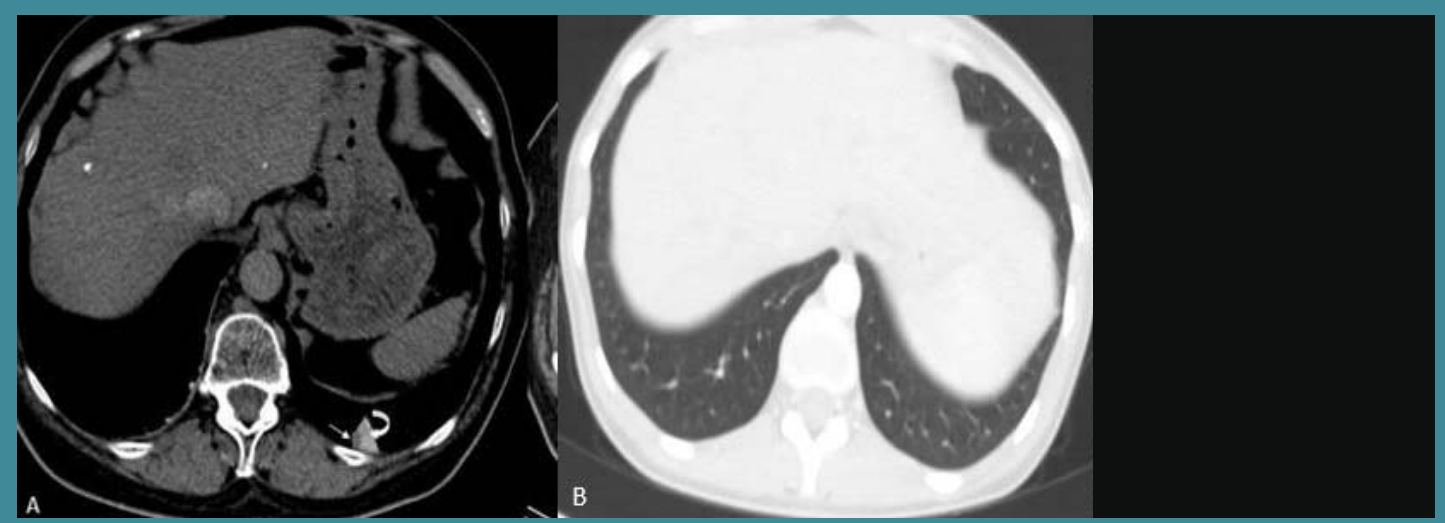

Figure 2. Pulmonary infarction. Focal pulmonary consolidation in the posterior segment of the left lower lobe ( $A$, curved arrow) in a patient with pulmonary thromboembolism. The lesion is wedge-shaped and has a heterogeneous internal structure with a small area of lucency (straight arrow) with no contrast enhancement. The infarct is surrounded by a thin area of passive atelectasis (round arrow, A). B. Folow-up CT scan performed 3 months later shows regression of the lesion.

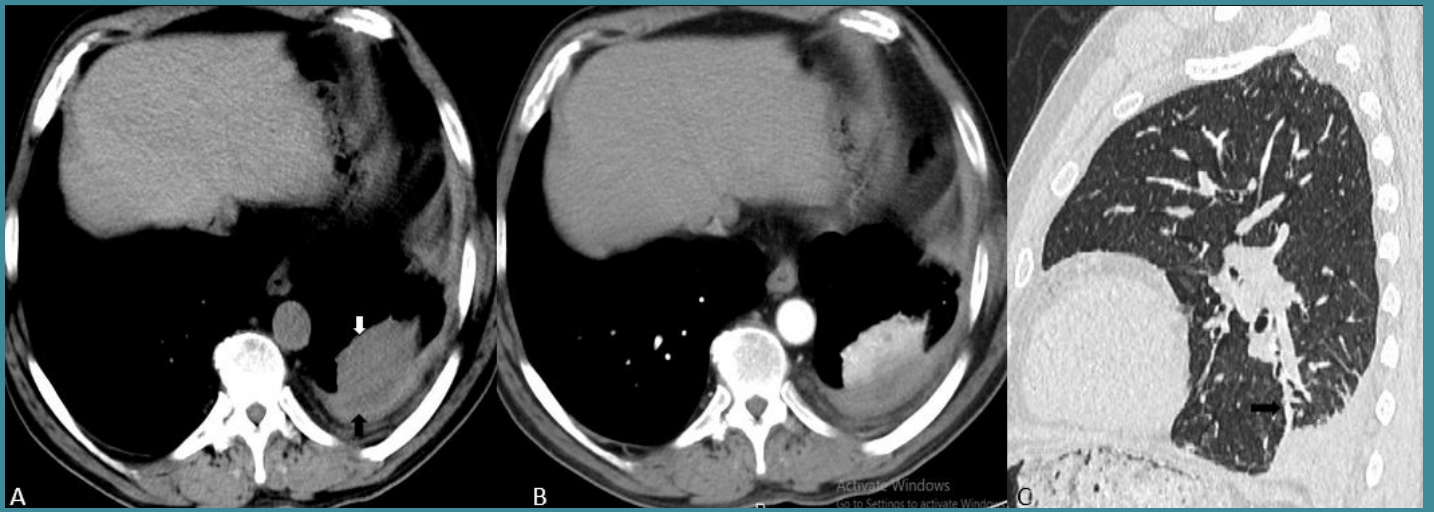

Figure 3. Round atelectasis. A. Axial non-contrast CT image shows a pulmonary mass in the posterior segment of the left lower lobe (white arrow), whith vivid enhancement after contrast administration (B). Note the location of the lesion and the acute angles with the pleural surfaces, the presence of pleural fluid on the left, with thickening of the pleura (black arrow, A) and the comet tail on the sagital image (black arrow, C). 


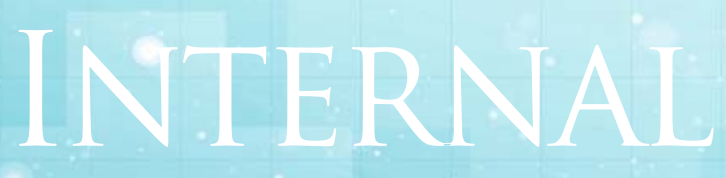

Clinical cases

sensitivity for pulmonary infarction ${ }^{(4)}$. The vessel sign, which refers to an enlarged vessel that led to the apex of infarct area, may be seen. Sometimes the lesion may cavitate, in septic embolism or infection of a bland embolus.

\section{Round atelectasis}

Round atelectasis is a collapse of the lung associated with pleural thickening that can mimic a lung cancer. It can be found in the literature under several names such as folded lung syndrome or Blesovsky syndrome, pleuroma, shrinking pleuritis with atelectasis, helical or cylindrical atelectasis. The mechanism of rounded atelectasis is not well understood, however several theories have been proposed. One theory associates round atelectasis with asbestos exposure and reports this lesion as one of the least common of all benign asbestos-induced pleural changes ${ }^{(5)}$.

Another theory postulates that round atelectasis develops during the resolution of a pleural effusion. According to this theory, a pleural effusion causes a local atelectasis in the adjacent lung. As a result the visceral pleura will infold and will cause the lung to tilt into the cleft. Then the lung will curve on itself in a concentric mode.

Regarding clinical findings and laboratory evaluation, round atelectasis is usually asymptomatic. Sometimes, the patients complain of cough, dyspnea or chest pain. A history of asbestos exposure or pleural effusion may help in the diagnosis. Physical findings may reveal deep inspiratory crackles but sometimes are minimal or absent. Laboratory tests are usually normal.

Several CT imaging characteristics help differentiate a round atelectasis from a malignant pulmonary mass. First of all, the round atelectasis has a comet tail, which is a specific sign for this lesion and can be seen in almost all cases. The comet tail sign is given by bronchi and vessels which enter the lesion. Another sign associated with round atelectasis is Crow's feet, linear bands that radiate from the mass into the lung parenchyma.

Secondly, the lesion is always located next to a pleural surface, in the periphery of the lung, and it forms acute angles with the pleural surfaces. Round atelectasis is usually situated in the posterior segments of lower lobes; sometimes, it is find on the diaphragm or in the upper lobes. The shape of the lesion is usually, is it name implies, rounded oval with speculated margins. At the periphery of the lesion, the aerated lung has a semilunar appearance and can be seen on both side of the lesion. An air bronchogram may be seen in the center of the lesion. It has a density close to that of soft tissue and enhances as typical lung parenchyma. As it is a collapsed lung, main stem bronchi or lung fissures may 

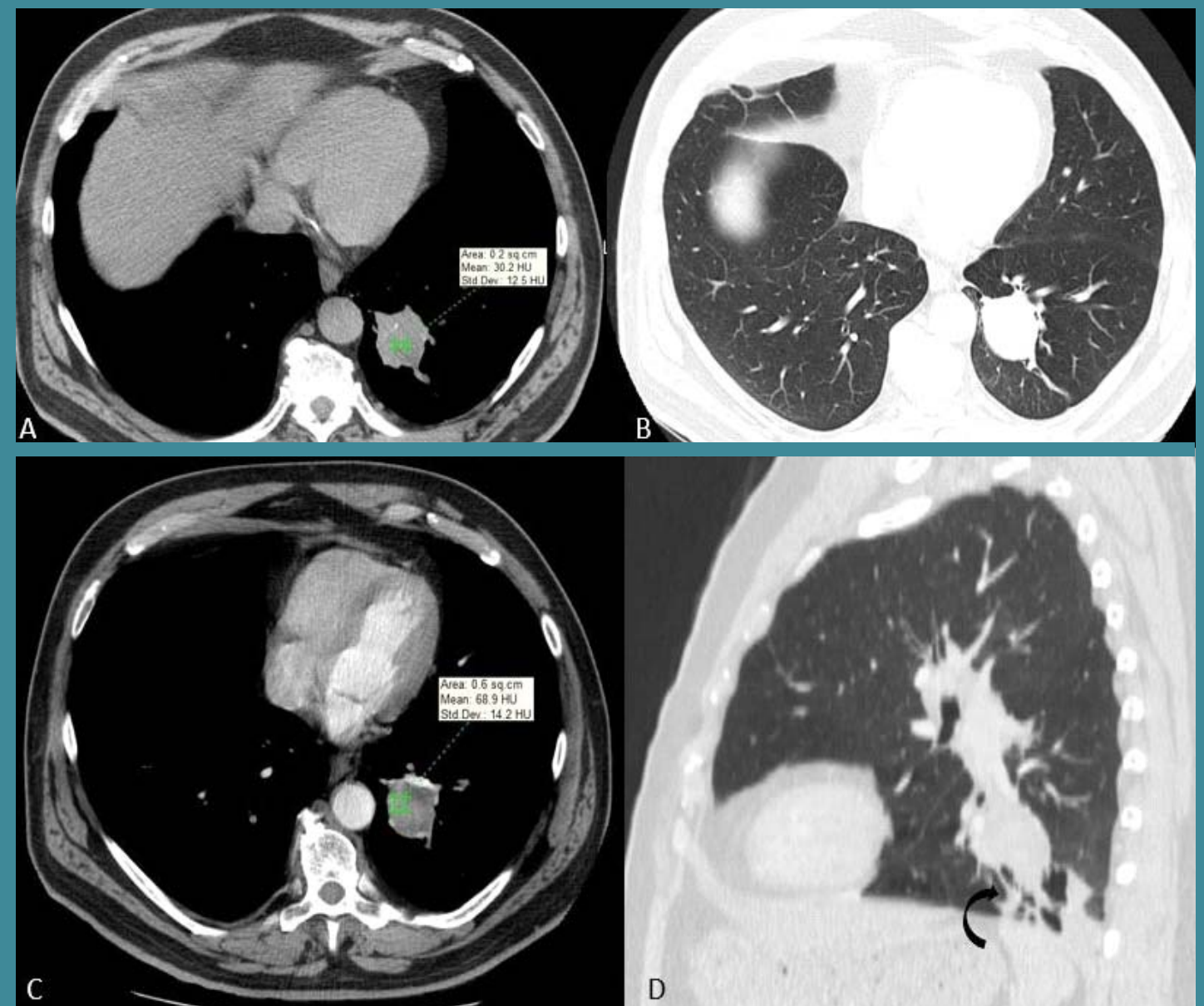

Figure 4. Pulmonary pseudoaneurysm. A, B - Axial non-contrast CT scan shows a nodular lesion adjacent to the left pulmonary vessels, relatively well delineated, with hematic densities (35-40 HU). Smooth linear calcification is seen on the antero-superior aspect of the lesion, indicating a calcified wall. C-Contrast enhanced CT demonstrates enhancement similar to the pulmonary artery; note that the enhancement is inhomogeneous due to partially thrombosed walls of the pseudoaneurysm. D - Sagital MPR reconstruction shows cylindrical bronchiectasis of the posterior segment of the lower lobe, which is the cause of the pulmonary pseudoaneurysm.

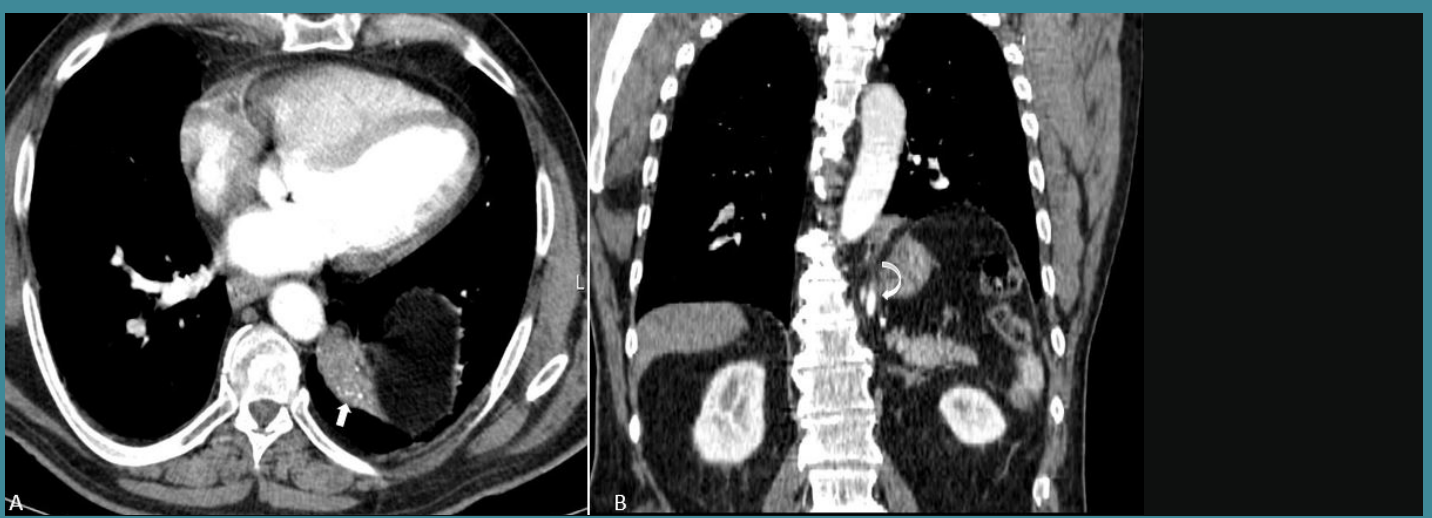

Figure 5. A. Extralobar pulmonary sequestration. A. Axial contrast-enhanced CT image shows a mass in the left lower lobe, with homogenous enhancement. B. Coronal contrast-enhanced CT image shows the arterial supply of the pulmonary sequestration, which is from the celiac trunk, and the venous drainage to the portal vein. 


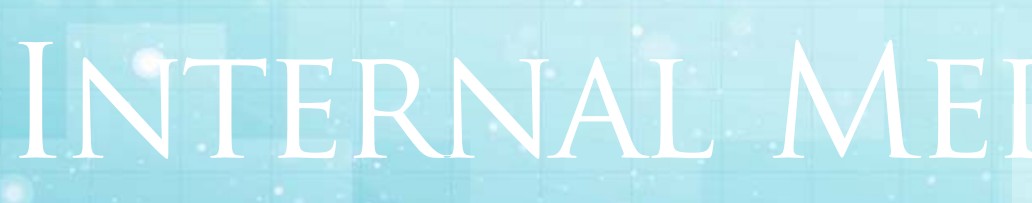

\section{Clinical cases}

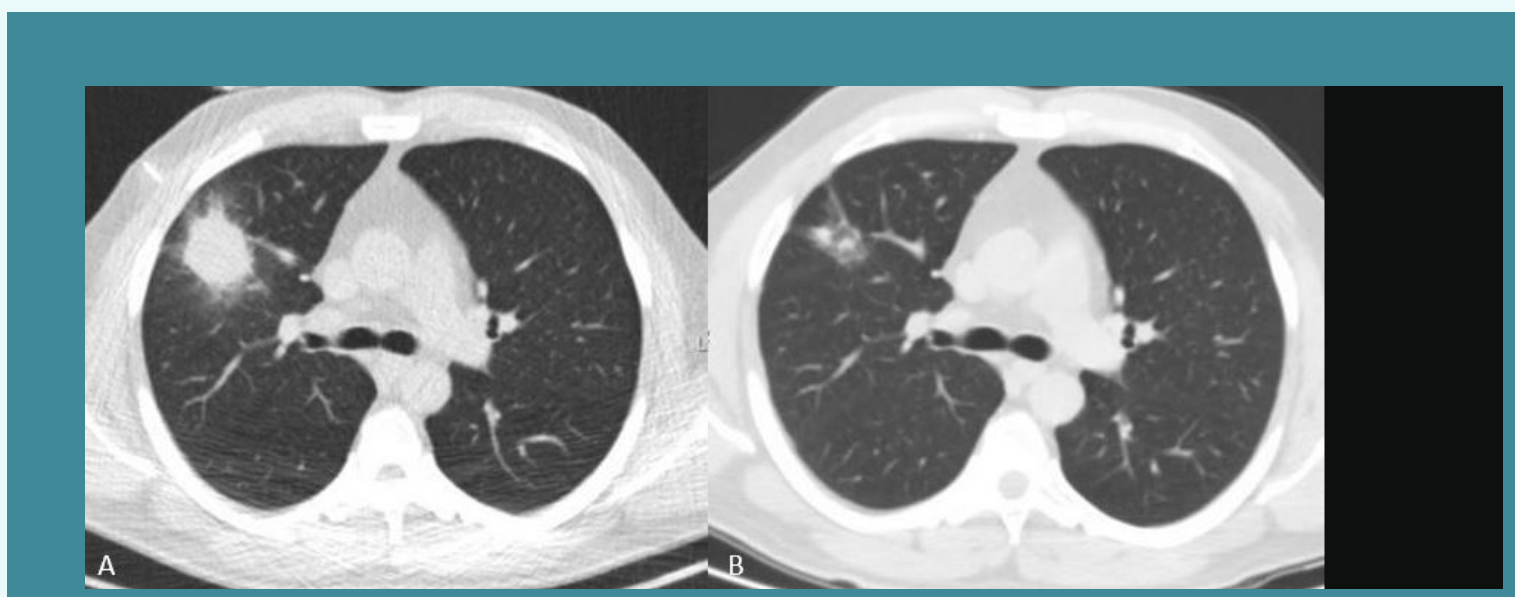

Figure 6. Inflammatory pseudotumour. A. Axial CT scan demonstrates an irregular pulmonary lesion, measuring $40 / 35 \mathrm{~mm}$ in diameter, located in the right upper lobe with extension in the medial lobe, in 46-year old patient complaining of cough and fever. No mediastinal lymph node detected. B. Follow-up CT scan 2 months later shows significant regression of the lesion.

be displaced. Mediastinal or hilar lymph nodes are not enlarged in round atelectasis. Several CT criteria have been proposed for the diagnosis of round atelectasis: oval or rounded pulmonary mass, $3,5-7 \mathrm{~cm}$ in diameter, located next to the pleural surface in the periphery of the lung, bronchovascular structures curving into the mass (comet tail sign), associated with pleural thickening ${ }^{(6)}$.

\section{Pulmonary artery pseudoaneurysm}

Pulmonary artery pseudoaneurysm is a focal dilatation of the artery that involves only the two external layers of the vessel wall: the media and adventitia. Pulmonary artery pseudoaneurysm is a rare finding but potentially fatally if ruptured. It may congenital or acquired; the most common causes of acquired pulmonary pseudoanerysm are infectious diseases, chest wall trauma or trauma from pulmonary catheters.

In pulmonary artery pseudoaneurysm, CT angiography is the gold standard examination and shows a fussiform or saccular lesion in continuity to a vessel, occasionally partially thrombosed. One key feature is that the lesions follows the same contrast density as the pulmonary artery in all phases of the examination. Other signs may be present such as thickened vessel wall indicating a vasculitis, traction bronchiectasis, tuberculosis or pyogenic infection ${ }^{(7)}$. They are usually solitary lesions, except the cases where they are caused by endocarditis or metastatic disease. 


\section{Pulmonary sequestration}

Pulmonary sequestration is a congenital lung abnormality characterized by a nonfunctioning portion of the lung that is not connected to the normal tracheobronchial tree and has systemic arterial supply. There are two types of pulmonary sequestration: intralobar (most frequent) and extralobar. Intralobar sequestration does not have a separate pleura and has venous drainage via pulmonary veins in most of the cases. Extralobar sequestration has separate pleura and the venous drainage is through systemic veins and right atrium. Overall, pulmonary sequestrations are located in the lower lobes; extrapulmonary sequestration affects usually the left lower lobe ${ }^{(8)}$. In $10 \%$ of cases, extralobar sequestration can be located infradiaphragmatically. It should be suspected in any patient with recurrent lower lobe pneumonia.

On chest radiography, pulmonary sequestration appears as a triangular opacity, with smooth or lobulated margins and heteregenous structure due to cystic spaces, if infected. Contrast enhanced CT scan clearly depicts the systemic arterial supply. Homogeneous enhancement of a soft-tissue mass, similar to aortic enhancement, is the key to diagnosis. An infected pulmonary sequestration has a more heterogenous structure with cysts containing air or fluid.

\section{Inflammatory pseudotumour}

Inflammatory pseudotumour is a reactive lesion that consists of inflammatory cells and myofibroblastic spindle cells. Many terms have been used to describe this disease including plasma cell granuloma, fibrous histiocytoma, inflammatory myofibroblastic tumour or xantogranuloma. The cause of this lesion is unknown. It is still a debate whether it is only an inflammatory lesion or a true neoplasm of benign nature or low-grade malignancy. The invasion of chest wall and mediastinum or local recurrence after resection support the latter hypothesis ${ }^{(9,10)}$. Some authors believe that the lesion is the result of an infection with various microorganisms such as Mycobacterium avium, Mycoplasma, Actinomyces, Corynebacterium equi, E. Coli, Klebsiella, Pseudomonas or Coxiella burnetti. Other authors believe that the inflammatory pseudotumour develops as a result of an immune-autoimmune mechanism or as a response following minor trauma or surgery. Inflammatory pseudotumour can occur in every site of the body but the most frequent locations are the lung and the orbit. Clinically, the patients may be asymptomatic or may describe cough, hemoptysis, history of previous infection, weight loss, fever or fatigue.

Regarding the imaging features, the inflammatory pseudotumour most often appears as a solitary, pulmonary nodule or mass, of up to $10 \mathrm{~cm}$ in diameter, with welldefined margins; sometimes it may have spiculated margins(11). It can have homogenous or heterogeneous attenuation due to hemorrhage, necrosis or calcification, and variable enhancement. Enlarged lymph nodes and cavitation are uncommon.

\section{Conclusions}

To sum up, the interpretation of a pulmonary lesion as benign or malignant is essential in the patient management. There is a wide range of pulmonary lesions that may mimic lung cancer. However, some of them exhibit certain imaging features that help differentiate them from malignant lesions. Understanding their etiology, radiological 


\section{INTERNAL Clinical cases}

features and clinical course is important in order not to interpret them as lung cancer and perform unnecessary pulmonary biopsies.

\section{References}

1. Heerink WJ, de Bock GH, de Jonge GJ, Groen HJ, Vliegenthart $R$, Oudkerk M. Complication rates of CTguided transthoracic lung biopsy: meta-analysis. Eur Radiol. 2017;27(1):138148. doi:10.1007/s00330-0164357-8

2.Manhire A, Charig M, Clelland C, et al Guidelines for radiologically guided lung biopsy, Thorax 2003;58:920936. 2.

3.AL Wagner, Radiologic manifestation of round pneumonia in adults, AJR:170, March1998

4.Kim, YW. \& Donnelly, L.F. Pediatr Radiol (2007) 37: 1235. https://doi.org/10.1007/s00247-007-0654-3
5.Webb WR, Higgins CB. Thoracic Imaging: Pulmonary and Cardiovascular Radiology, North American Edition. Lippincott Williams \& Wilkins. (2010) ISBN:1605479764. 6.Georgios T.Stathopoulos, Rounded atelectasis of the lung, Respiratory Medicine, Volume 99, Issue 5, May 2005, Pages 615-623

7.Furuya K., CT mimics of lung cancer, AJR:199, October 20127.

8. Ying Chen et al, Pulmonary Artery Pseudoaneurysms: Clinical Features and CT Finding, American Journal of Roentgenology 2017 208:1, 84-91

9. Deepa R. Biyyam, Congenital lung abnormalities: Embriologic features, prenatal diagnosis, and postnatal radiologic-pathologic diagnosis, Radiographics 2010.

10. Mondello B, Surgical management of pulmonary inflammatory pseudotumors: A single center experience, Journal of Cardiothoracic Surgery20116:18 11. Lakshmana Das Narla, Inflammatory pseudotumour, RadioGraphics 2003; 23:719729 